https://doi.org/10.30843/nzpp.2019.72.320

\title{
Current and planned research for managing the risk of Xylella fastidiosa to New Zealand
}

Sandra B. Visnovsky ${ }^{1,3^{*}}$, Robert K. Taylor ${ }^{2,3}$ and David A.J. Teulon ${ }^{1,3}$

${ }^{I}$ The New Zealand Institute for Plant and Food Research Ltd, Private Bag 4704, Christchurch 8140, New Zealand

${ }^{2}$ Plant Health and Environment Laboratory, Ministry for Primary Industries, PO Box 2095, Auckland 1140, New Zealand

${ }^{3}$ Better Border Biosecurity (B3) (www.b3nz.org)

*Corresponding author: Sandra.Visnovsky@plantandfood.co.nz

Xylella fastidiosa $(X f)$, a xylem-limited bacterium native to the Americas, has a devastating impact on many crops internationally. In California, $X f$ causes over USD 100 million in yearly losses to the grape industry and infects an estimated 200 million citrus trees in Brazil. More recently, $X f$ killed around one million olive trees on the Italian peninsula of Salento. Xylella fastidiosa is not known to be present in New Zealand. The glassy-winged sharpshooter (Homalodisca vitripennis), an important vector of $X f$ in California, is also not present in New Zealand. However, the meadow spittle bug (Philaenus spumarius), an important vector of $X f$ in Italy, is present. Many economically important horticultural, viticultural, agricultural, amenity and indigenous/native plant species, including taonga, are likely to be susceptible to $X f$. Aspects of our research on $X f$ to understand the impact, reduce the likelihood of entry into New Zealand and/or minimising its impact in New Zealand will be presented. The research listed on the poster spans risk assessment, diagnostics, surveillance and biological control but could certainly be increased across the biosecurity continuum given the magnitude of the threat from $X f$ to New Zealand's valuable plant systems.

https://doi.org/10.30843/nzpp.2019.72.6980

\section{Semi-commercial hot water treatments for control of bull's eye rot of apples}

Luna Hasna ${ }^{1}$, Kerry R. Everett ${ }^{1}$, Michelle J. Vergara ${ }^{1}$, I.P. Shamini Pushparajah ${ }^{1}$, Peter N. Wood ${ }^{2}$, Brent M.

Fisher $^{2}$, Lucia Ramos ${ }^{1}$, Carol Middleditch ${ }^{1}$, Shane Olsson ${ }^{1}$, Agam Nangul ${ }^{1}$, Jung Ook Cho ${ }^{1}$ and Allan B. Woolf ${ }^{1}$

The New Zealand Institute for Plant \& Food Research Limited.

${ }^{1}$ Mt Albert Research Centre, Private Bag 92169, Mt Albert, Auckland 1142, New Zealand

${ }^{2}$ Havelock North Research Centre, Private Bag 1401, Havelock North, New Zealand

Corresponding author: Kerry.Everett@plantandfood.co.nz

Bull's eye rot (BER) of apples is caused by a postharvest fungal pathogen (Phlyctema vagabunda syn. Neofabraea alba). Previous laboratory experiments found hot water treatments (HWT) resulted in a significant reduction of BER incidence for artificially inoculated fruit so the feasibility of HWT to control naturally infected fruit in a semi-commercial trial was tested. One bin (1934 fruit) of naturally infected 'Scired' apples was harvested from a Hawke's Bay orchard with a known high incidence of BER, then placed in a coolstore for 1 week until treated. All fruit were passed through a high-pressure water blaster then air dried. Approximately half the contents of the bin (1034 fruit) were packed into Friday trays in apple boxes with a plastic polyliner. The other half (900 fruit) were treated for 2 min with hot water at $51^{\circ} \mathrm{C}$ in a semi-commercial hot water bath before packing. All fruit were then coolstored for 20 weeks before assessment for BER. This HWT resulted in a 6-fold reduction of BER incidence so was an effective treatment for BER in a semi-commercial test. 